\title{
The Impact of Research and Development and Professional New Hiring on Organizational Innovation
}

\author{
Dankyi Alex Boadi (Corresponding author) \\ School of Finance Economics, Jiangsu University, China \\ E-mail: alexboadidankyi@stmail.ujs.edu.cn \\ Dankyi Joyce Kwakyewaa \\ College of Distance Education, University of Cape Coast, Ghana \\ E-mail: joyce.dankyi@ucc.edu.gh \\ Abban Joseph Olivier \\ School of Finance and Economics, Jiangsu University, China \\ E-mail: olinax90@stmail.ujs.edu.cn
}

Asabea Addo Antoinette

School of Management, Jiangsu University, China

E-mail: asabeaaddoa@stmail.ujs.edu.cn

Received: February 4, 2020 Accepted: March 6, 2020 Published: March 10, 2020

doi: 10.5296/hrr.v4i1.16385 URL: https://doi.org/10.5296/hrr.v4i1.16385

\begin{abstract}
Organizational innovation is highly dependent on the inflow of relevant information and proper integration of this information in the operational processes for a process, product and service innovation. Employee engagement and social connectedness of employees have been cited as key methodologies of integrating new information from research and development and professional new hiring. The study investigated the impact of research and development and professional new hiring on organizational innovation jointly mediated by employee
\end{abstract}


engagement and social connectedness. A structural equation model was adopted for the study. The estimator adopted in testing the hypothetical model and the hypothesis was a maximum likelihood. A comparative analysis of the single mediating and the joint mediating of employee engagement and social connectedness was conducted. The results indicated that professional new hiring and research and development activities have a statistically significant indirect effect on organizational innovation through a joint mediation of social connectedness and employee engagement. The threshold for the model fitness was satisfied. The study, based on the findings on both the decomposed and final model, concludes that employee engagement and social connectedness jointly influence the relationship between the research and development and professional new hiring on organizational innovation better than the single mediation.

Keywords: Employee engagement, Social connectedness, Research and development, Professional new hiring, Organizational innovation, Banking

\section{Introduction}

The backbone of the organizations' sustainability in the competitive environment is innovation. In the view of Knoke and Kalleberg (1994), the success of organizations in this present day is dependent on the acceptance of high investments in training and development to acquire the greatest return on human capital for innovative and competitive advantage. Economic constraints, however, require that due diligence is made during employment processes to ensure that employees possess the right set of knowledge that will help the organization keep up with the galloping innovation trends. This places hiring on a unique platform in its contribution to organizational innovation.

A well-established concept in organizational learning is the dependence of organizational innovation on newness (Bantel \& Jackson, 1989; Wang \& Zatzick, 2019). Deductively, the importance of recruiting for new knowledge, skills, ideas, and perspectives is key to innovation. New hires enter organizations with novel knowledge, perspective, skillset and ideas which when well exploited for organizational innovation extends the stock of knowledge and process innovativeness. Herstad, Sandven, and Ebersberger (2015) argue that new employees' knowledge, skill set and perspective of process and product tends to mix up with organizational existing knowledge, skill set and perspective leading to improvements and changes in the organizational processes and outcomes as well. Other researchers support the contribution of new hiring in improving and ensuring the sustainability of organizations through innovation. Researchers such as Gallivan (2001); Marchington (2015); Rousseau (1997); Ulrich and Dulebohn (2015) have acknowledged the fundamental principle of the need to engage new hiring to remain innovative.

Organizations lose human resources through compulsory retirements, competitions in the market and other turnovers and the replacement of these former employees is crucial in determining organizational growth and sustainability. Premising from the Context-Emergent Turnover (CET) theory, the more or better knowledge, skillset, abilities and other human capital characteristics acquired from new hires, the greater the offset of the human capital lost and the greater the improvement in organizational innovation, (Bamberger, Biron, \& Meshoulam, 2014; Nyberg, Moliterno, Hale Jr, \& Lepak, 2014). 


\section{MInstitute ${ }^{\text {Mink }}$}

A key traditional methodology for organizational innovation is through Research and Development (Yukiko, 2016). Over the decades, research and development have given many firms an upper hand in innovation in the competitive industrial workspace. Dinçer, Yüksel, Adal1, and Aydin (2019) posits that organizations that consider research and development as a key contributor to innovation mostly niche large market shares in innovation.

Other studies have argued that hiring in itself is not conclusively predictive of organizational innovation. Creelman (2019) posits that hiring stars, thus highly talented workers, can negatively impact a company's performance if other factors are not duly put in place and well managed. From his position, an obvious query into the factors that enhance organizational cohesion and innovation will ensure the integration of new hires and gain the maximum benefits from their new knowledge, skill-sets, and perspectives.

Gallivan (2001) explains that literature on organizational learning by hiring hinges on the idea that tacit knowledge of new hires diffuses into the organization usually as immediate as their recruitment, however, their integration into organizational processes and outcome takes much more time and other interventions on the part of both the employee and employer. The assumption of an increase in hiring increasing organizational knowledge is, therefore, not always the case as new hires and incumbent scramble for scarce resources such as promotion, recognition, and opportunities (Herstad et al., 2015). Our study, therefore, introduces employee engagement as it promotes efficient communication, participation, idea and information sharing and finally builds trust, which research findings authenticate as an aid in enlarging the benefits of increased hiring for organizational innovation, (Camarinha-Matos, Afsarmanesh, Galeano, \& Molina, 2009; Foskett, 2005; Huxham \& Vangen, 2013; Liedtka, 1996).

In spite of the numerous studies on new hiring and organizational innovation, little or no theoretical or empirical research has investigated how the characteristics of new employees like social connectedness mediate the relationship between new hiring and organizational innovation. In organizational studies and culture, the social connectedness of employee assesses employees' openness to relate positively with colleagues at the workplace. Research shows that the ultimate competitive advantage for a knowledge-based organization in today's information age is its human resource. In the right context, the right caliber of employees can make good organizations great, in large part through their positive, high-quality relationships (Landherr, Friedl, \& Heidemann, 2010). We advance this line of research by systematically theorizing and testing the mediating role of social connectedness in organizational innovation.

Our study proposes that organizational new hiring and research and development together impact organizational innovation through a joint mediation of employee engagement and social connectedness.

\subsection{Originality/Value}

Our study seeks to contribute to the yet to be fully defined field of study, thus, organizational hiring and innovation in an integrated way. This research introduces a novel idea about the joint mediating role of network participation and employee engagement in the relationship between new hiring and organizational innovation. Again, we consider a covariance 
relationship between new hiring and research and development. We theoretically argue that employee engagement practices and social connectedness jointly mediate the relationship between new hiring and research and development on organizational innovation.

\section{Theories and Hypothesis Development}

\subsection{Organisational Innovation, New Hiring, and Research and Development}

Innovation has been the gripping tool in an organization having an upper hand in market shares, increasing profits and securing growth now and in the future. Thus, the ability of an organization to innovate is a pre-condition for the successful deployment of inventive resources and new technologies. From the ground-breaking works of Schumpeter (1934), many researchers and scholars, in general, operationalize innovation by focusing on the concept of newness. Theories of organizational cognition and learning tend to focus on the process of how organizations develop new ideas for problem-solving. Studies in this direction of innovation focus on the cognitive foundations of organizational innovation which is an offspring of the learning and organizational knowledge creation process (Battistelli, Odoardi, Vandenberghe, Di Napoli, \& Piccione, 2019; Kogut \& Zander, 1992). In this context, researchers in this field provide an understanding in relation to the capacity of organizations to create and exploit new knowledge necessary for innovative activities. One key way by which organizations fuel their innovation is through new hiring. New hires arrive in the organization with new ideas, knowledge, skills, and perspectives that they have gained through their work and environmental experiences as well as their education (Ahmad, Kura, Bibi, Khalid, \& Jaaffar, 2019; Kogut \& Zander, 1992).

Call, Nyberg, Ployhart, and Weekley (2015) posits that the Content-Emergent Turnover theory advances that the strategic introduction of new hiring with fresh knowledge, perspectives and skillsets are not only to replace the lost human capital but also to properly integrate with the existing knowledge base to advance organizational innovation. Hiring has strategic implications beyond mere counteracting the loss of human capital. An organizations' source of hiring; internal, external, inter-organizational or intra-organizational have a different impact on organizational performance, (Birasnav, Chaudhary, \& Scillitoe, 2019; Jeong \& Shin, 2019) which affords the organization sustainable and competitive human resources.

Similarly, other researchers argue that Research and Development (R\&D) is a key determinant of growth (Awaworyi Churchill, Ugur, \& Luong, 2020; Kawajiri, Goto, Sakurai, Hata, \& Tahara, 2020; Varga, Sebestyén, Szabó, \& Szerb, 2020). According to Romer (1989), investment in $R \& D$ projects is crucial to utilizing human capital and existing knowledge for technology development. Recent literature supports the importance of R\&D expenditure investments in increasing innovation. Investing in $R \& D$ is critical to innovation and is considered a competitive advantage for firms and the economy (Chen, Liu, Suárez Serrato, \& Xu, 2018; Dhaoui \& Jouini, 2019; Strandholm, Espinola-Arredondo, \& Munoz-Garcia, 2018). Various studies have shown that there is a positive link between R\&D expenditure and organizational growth (Choi \& Yi, 2018; Li \& Hall, 2018; C. Liu \& Xia, 2018; N. Liu \& Fan, 2020; Saidi \& Mongi, 2018)

The study, therefore, hypothesizes that: 
H1a: Organizational new hiring has a positive influence on employee engagement.

H1b: Organizational new hiring has a positive influence on social connectedness

H1c: Employee engagement and social connectedness have a joint mediating effect on organizational new hiring and innovation.

H2a: Research and Development have a positive influence on social connectedness.

H2b: Research and Development have a positive influence on employee engagement.

H2c: Employee engagement and social connectedness have a joint mediating effect on Research and Development and innovation.

\subsection{Social Connectedness}

Social connectedness projects the set of interpersonal relationships acquired through networks and connections, mutual understanding and support from formal and informal groups among others that creates value for individuals in the organization (Birasnav et al., 2019; Ferris, Javakhadze, \& Rajkovic, 2017). Social capital unconsciously influences one's decision in many ways. Deductively, from the works of Birasnav et al. (2019), sometimes one might not necessarily realize that their actions or inactions are influenced by their trust or beliefs inherited through a social network. Explicitly, social capital can be a dormant or an active threat that influences one's decisions thereby leveraging decision making. We, therefore, hypothesized that;

H3: Social connectedness will have a positive influence on employee engagement.

H5: Social connectedness will have a positive influence on organizational innovation.

H6. Social connectedness mediates the relationship between new hiring, employee engagement, and organizational innovation.

\subsection{Employee Engagement}

Research has shown that organizations with high employee engagement excel in customer satisfaction and achieve high productivity and operational efficiency as well as profitability with the additional side effect of safer, healthier employees with lower absenteeism and reduced turnover. In Collins (2001) on the quest of organizations moving from 'Good' to 'Great', he opines in a summarized statement that "when the 'Right' persons are put in the 'Right' position and are provided with the 'Right ' resources, they can do the 'Right' thing at the 'Right' time".

Through the employment of the services of new employees, organizations have access to the knowledge, ideas, skill-sets, and experiences of the new recruits, it, however, need to possess integrative knowledge management tools to ensure effective utilization and integration of the human capital for organizational innovation (Tomar, 2020; Turner, 2020). Employee engagement in general looks at the methodological ways of adding or creating value by actively leveraging human capital (Shujahat et al., 2019; Tomar, Khandelwal, \& Jain, 2020).

One key way of transforming the accessed knowledge, skills-sets and ideas are through employee engagement where continual sharing of ideas, skills, and knowledge is perpetually cultivated through conscious policy-oriented practices for organizational innovation. Deductively, organizations that consciously promote employee involvement in shaping processes and products increase the likelihood that their new hiring's perspectives, ideas, and 


\section{Macrothink

knowledge sets will be diffused effectively with existing ones to niche organizational innovation. Tomar (2020) expressed that scholars in the area of organizational effectiveness have identified four major elements in the work environment that fosters high worker involvement; power, information, knowledge, and recognition. Employee engagement presents unique opportunities to both new and old employees to share their knowledge, take on more challenging assignments, learn from others, all of which will help in the reduction of rigid routines, familiarity trap and maturity trap that hinders organizational innovation (Ahuja \& Morris Lampert, 2001)

Our study, therefore, hypothesizes that;

H4: Employee engagement has an influence on organizational innovation.

\subsection{Framework}

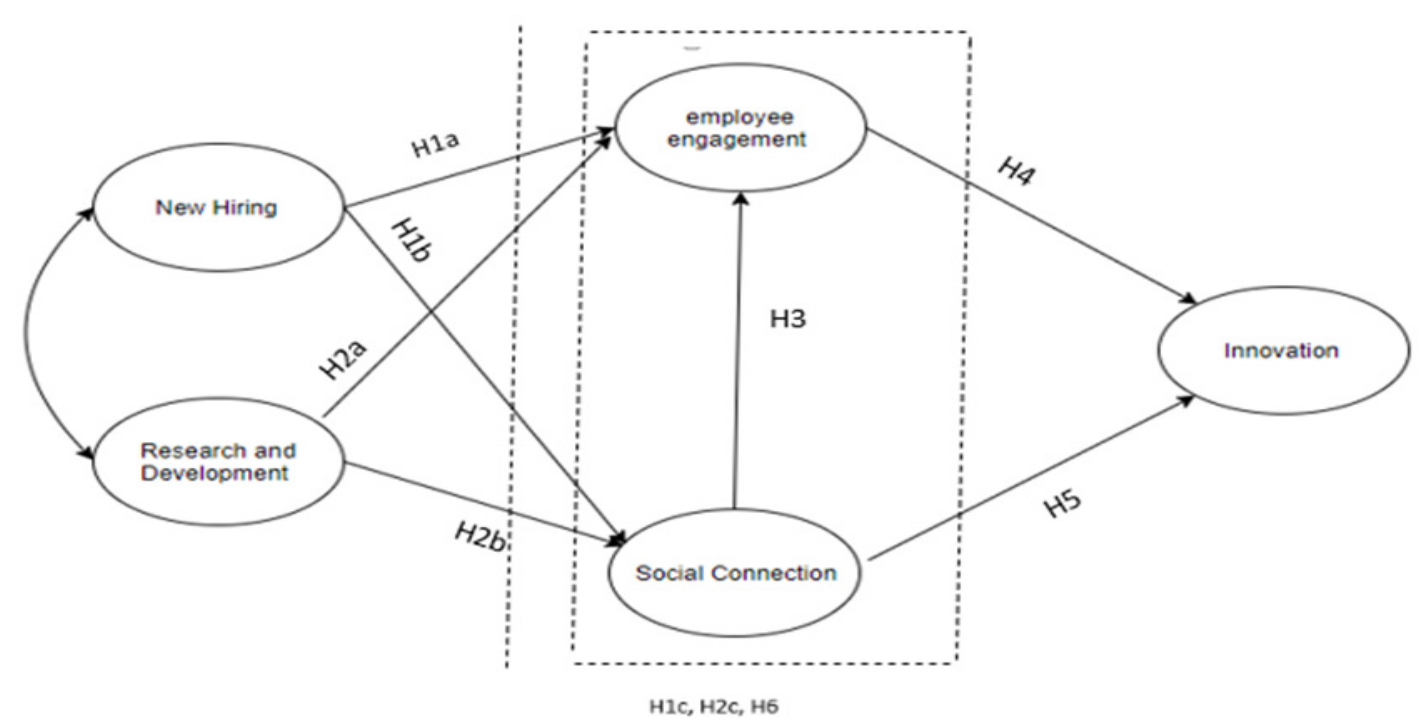

Figure 1. Conceptual Framework

Figure 1 represents the conceptual framework for the study. Summarizing from Figure 1, we argue that Organizational New Hiring and Research and Development together have a positive influence on Organizational Innovation. The position is based on the assumption that all new employees possess unique human capital (knowledge, skill-sets, ideas, and perspectives) that justify their selection in the employment processes into the organization. Further, through research and development organizations consciously or accidentally innovate their services, products, and processes. Organizational Innovation was assessed on newness and improved perspective in terms of processes, products, and services.

Again from the conceptual framework in Figure 1, our study posits that the relationship between organizational new hiring, research, and development and organizational innovation is jointly mediated by employee engagement and participatory networks. Deductively, the relationship is dictated by the employee engagement policies and practices within the organization as well as employee characteristics of involvement or participation in social networks like professional associations. 


\section{Macrothink}

\section{Methodology}

\subsection{Sample}

Our study sample design comprised of a probability sample of 1075 employees of seven listed banks on the Ghana Stock Exchange (GSE). All the 64 managerial staff of the 7 listed banks under consideration were added while 150 participants from each of the 7 banks were equally sampled for the study. The computer-generated random sampling method based on the reference list (staff list) was used for convenience. The listed Banks under consideration included Access Bank, Agricultural Development Bank, CAL Bank, EcoBank, GCB Bank, HFC Bank, and Standard Chartered Bank Limited. The participants cut across different levels within the organization (managerial, middle-level employees and low-level employees). Out of the 1,114 questionnaires distributed, 1075 were retrieved representing a retrieval rate of $96.5 \%$.

\subsection{Measures}

\subsubsection{Organizational New Hiring}

In light of measuring organizational new hiring, the measurement scale was adopted from the work of Wang and Zatzick (2019) The measurement assessed the rate of hiring as well as patterns of hiring.

\subsubsection{Organizational Innovation}

We adopted Bedford, Bisbe, and Sweeney's (2019) performance measurement system that broadly categorizes organizational innovation into incremental achievements and radical achievements. Thus, radical achievements in context were viewed as entirely new processes or products/services while incremental achievements represented improved processes or products/services, (Bernal, Maicas, \& Vargas, 2019; Holmquist \& Johansson, 2019).

\subsubsection{Employee Engagement}

In measuring employee engagement, Joubert and Roodt's (2019) constructs were adopted. Employee engagement in this model considered three (3) levels of engagement namely; Individual Engagement, Team Engagement and Management Engagement in assessing the pull and push factors. Individual Engagement was measured using performance feedback, autonomy, workload, emotional demands, physical demands, and social support. Team Engagement was measured using supportive team climate, teamwork, coordination, team conflict, and team engagement scale. Management Engagement was measured using manager self-efficacy, organizational support, resources, advancement opportunities, and job insecurities.

\subsubsection{Social Connectedness}

In relation to the social connectedness of employees, we adopted and adapted the Social Connectedness Scale-Revised by Lee, Draper, and Lee (2001).

\subsection{Data Analysis Approach}

SPSS 25 and AMOS 23 software were used as statistical tools to calculate the descriptive, measurement model, structural model, and multi-group analysis to assess the predictive power of our proposed conceptual model in addressing innovation issues at the organizational level. We adopted Ogunmokun, Eluwole, Avci, Lasisi, and Ikhide's (2020) two-step approach. 


\section{Macrothink}

Human Resource Research

ISSN 1948-5441

2020, Vol. 4, No. 1

Firstly, the measurement model was tested to ensure that the indicator variables represented respective latent variables. Secondly, the structural model was tested by examining the path associations among constructs in our proposed model.

In our study, research and development, organizational new hiring, employee engagement, social connectedness, and innovation all contained multiple measurement items. We, therefore, adopted principal component analysis to extract the items in order to avoid measurement errors caused by multiple items within the same latent variable. Table 1 shows the goodness of fit indices and their threshold. From Table 1, our model was confirmed as an excellent fit between the data and the model itself in testing the relationship between all constructs within the structural model.

Table 1. Goodness fit test and their indexes

\begin{tabular}{llll}
\hline Goodness Fit Index & Abbreviation & Measured & Threshold \\
\hline Root Mean Square Error of Approximation & RMSEA & 0.045 & $<0.05$ \\
Normal Fit Index & NFI & 0.924 & $>0.09$ \\
Comparative Fitness Index & CFI & 0.961 & $>0.09$ \\
Incremental Fitness Index & IFI & 0.962 & $>0.09$ \\
Relative Fit Index & RFI & 0.909 & $>0.09$ \\
Tucker Lewis Index & TLI & 0.953 & $>0.09$ \\
Goodness of Fit Index & GFI & 0.943 & $>0.09$ \\
Adjusted Goodness of Fit Index & AGFI & 0.924 & $>0.09$ \\
Root Mean Square Residual & RMSR & 0.042 & $<0.05$ \\
Parsimony Goodness of Fit Index & PGFI & 0.705 & $>0.50$ \\
PCLOSE & PCLOSE & 0.947 & $>0.90$ \\
\hline
\end{tabular}

Source: AMOS generated from field data.

From Table 1, each of the fitness indices compared to their threshold performed better, validating the fitness of the model in predicting organizational innovation (Effendi \& Matore, 2019; STANLEY \& FREDERICK, 2020; Xia \& Yang, 2019).

\section{Results}

\subsection{Convergent and Discriminant Validity}

\subsubsection{Construct Validity}

O'Leary-Kelly and J. Vokurka (1998) points out that construct validity pertains to the degree to which the measure of a construct sufficiently measures the intended concept. The average variance extracted and composite reliability was used to estimate the reliability of the construct. 


$$
\begin{gathered}
A V E=\frac{\sum_{i=1}^{k} \lambda_{i j}{ }^{2}}{\sum_{i=1}^{k} \lambda_{i j}{ }^{2}+\sum_{i=1}^{k} \varepsilon_{i j},} \\
\frac{\left(\sum_{i=j}^{k} \Lambda_{i j}\right)^{2}}{\left(\sum_{i=j}^{k} \lambda_{i j}\right)^{2}+\sum_{i=1}^{k} \varepsilon_{i j} .}
\end{gathered}
$$

$$
\begin{aligned}
& \lambda_{i j}=\text { Factor loading of the item } i j \\
& \varepsilon_{i j}=\text { the variance of the error of the item } i j
\end{aligned}
$$

Table 2. Descriptive statistics of the constructs and the convergent and discriminant validity $\mathrm{N}=(1075)$

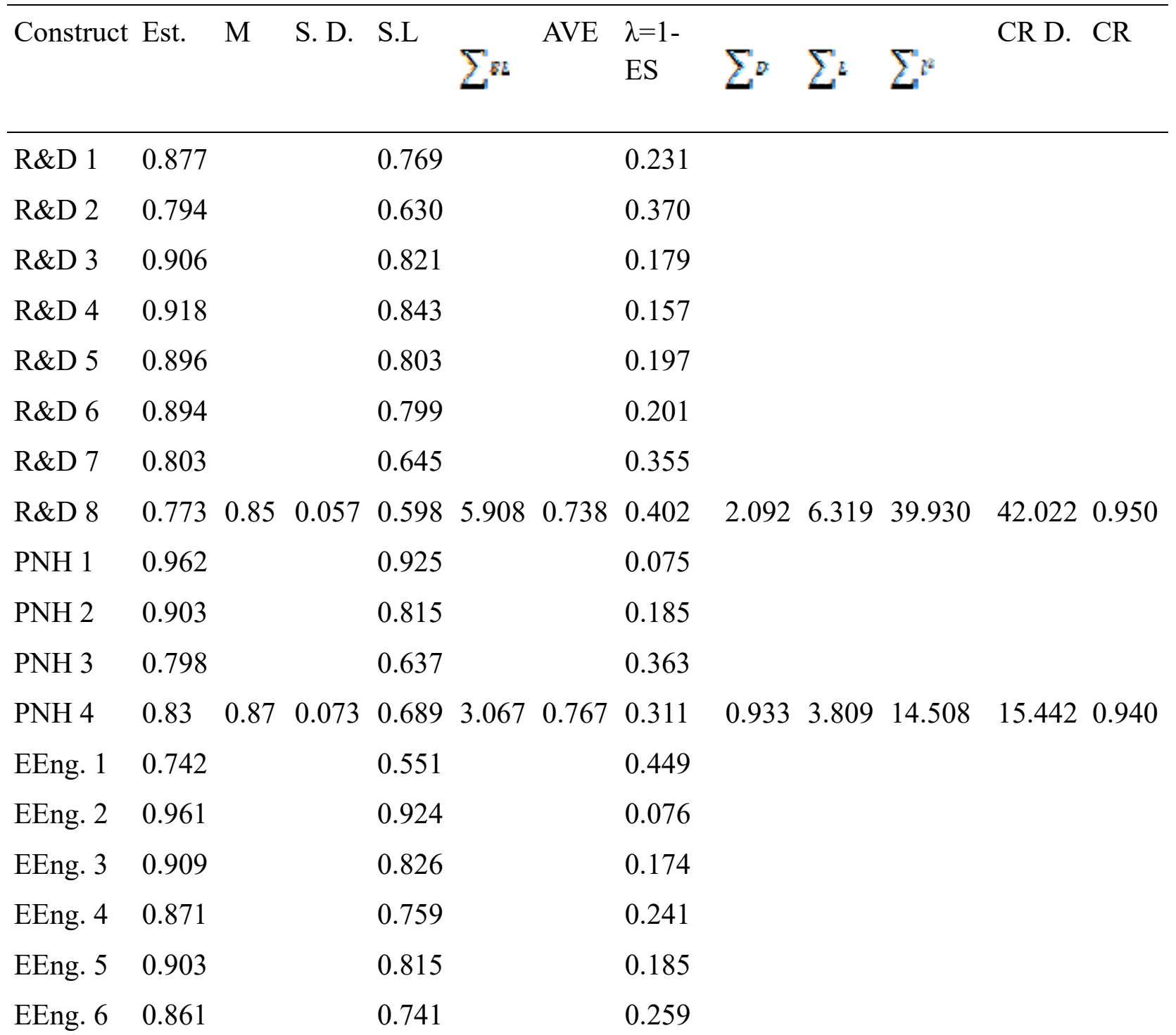




\begin{tabular}{|c|c|c|c|c|c|c|c|c|c|c|c|}
\hline EEng. 7 & 0.879 & & & 0.773 & & & 0.227 & & & & \\
\hline EEng. 8 & 0.941 & & & 0.885 & & & 0.115 & & & & \\
\hline EEng. 9 & 0.962 & & & 0.925 & & & 0.075 & & & & \\
\hline EEng. 10 & 0.971 & 0.9 & 0.068 & 0.943 & 8.142 & 0.814 & 0.057 & 1.858 & 8.945 & 80.013 & $\begin{array}{lll}81.871 & 0.977\end{array}$ \\
\hline S.C 1 & 0.841 & & & 0.707 & & & 0.293 & & & & \\
\hline S.C 2 & 0.903 & & & 0.815 & & & 0.185 & & & & \\
\hline S.C 3 & 0.864 & & & 0.746 & & & 0.254 & & & & \\
\hline S.C 4 & 0.872 & & & 0.760 & & & 0.240 & & & & \\
\hline S.C 5 & 0.923 & & & 0.852 & & & 0.148 & & & & \\
\hline S.C 6 & 0.767 & & & 0.588 & & & 0.412 & & & & \\
\hline S.C 7 & 0.952 & & & 0.906 & & & 0.094 & & & & \\
\hline S.C 8 & 0.794 & 0.86 & 0.062 & 0.630 & 6.007 & 0.751 & 0.370 & 1.993 & 6.871 & 47.211 & $49.204 \quad 0.959$ \\
\hline Inno 1 & 0.926 & & & 0.857 & & & 0.143 & & & & \\
\hline Inno 2 & 0.775 & & & 0.601 & & & 0.399 & & & & \\
\hline Inno 3 & 0.809 & & & 0.654 & & & 0.346 & & & & \\
\hline Inno 4 & 0.914 & 0.85 & 0.075 & 0.835 & 2.948 & 0.737 & 0.165 & 1.052 & 3.21 & 10.304 & 11.3560 .907 \\
\hline
\end{tabular}

Note. Loadings are standardized and significant with $p<0.1$. Estimate $=$ Est., Mean=M, CR.D Composite reliability denominator, Squared loadings (Estimate squared) - S.L, Sum of squared loadings $=\Sigma S L$, Sum of delta $=\Sigma D$, the sum of loadings $-\Sigma L$, the sum of loadings squared $=\underline{\Sigma} l^{2}$

Table 2 indicates the results of the convergent and discriminant validity measurement model. Fornell and Larcker (1981) propose a 3-way criterion for assessing the convergent validity of a model. First, they posit that all indicator loadings should exceed 0.65. Secondly, the composite reliability (CR) should exceed 0.80 and finally, the Average Variance Extracted (AVE) for each construct should exceed 0.50. Observable from Table 2, our results revealed that the convergent validity of measured constructs satisfied all the 3-way criteria set, as C.R, AVE and loadings all performed better in their assessment against the criteria thresholds. 
Table 2. Discriminant validity

Correlation between Constructs

\begin{tabular}{llllll} 
& R\&D & PNH & EEng & SC & Ino \\
\hline R\&D & $\mathbf{0 . 8 6}$ & & & & \\
PNH & $0.66^{* *}$ & $\mathbf{0 . 8 8}$ & & & \\
EEng & $0.70^{* *}$ & $0.70^{* *}$ & $\mathbf{0 . 9 0}$ & & \\
SC & $0.74^{* *}$ & $0.70^{* *}$ & $0.79^{* *}$ & $\mathbf{0 . 8 7}$ & \\
Ino & $0.65^{* *}$ & $0.67^{* *}$ & $0.81^{* *}$ & $0.80^{* *}$ & $\mathbf{0 . 8 6}$ \\
\hline
\end{tabular}

The correlational matrix of the constructs and the products of the square root of the calculated AVE are bolded in the diagonal.

\subsubsection{Discriminant Validity}

Bagozzi (1982) on evaluating the discriminant validity suggested the maximum limit of 0.90 in the constructs correlation matrix. From Table 3, all the construct correlation matrix had values less than 0.90. Further, Fornell and Larcker (1981) suggested that the value of the square root of the Average Variance Extracted (AVE) of a latent variable should be more than the value of the correlation between the rest of the latent variables. Table 3 showed that all the values of the square root of the AVE are greater than the correlation of the constructs and conclusively robust in discriminant validity.

\subsection{Structural Equation Model and Hypothesis Testing}

Our study assessed the structural model after the confirmatory model analysis of the constructs. Figure 2 indicates the results of the structural model analysis. Observably, Figure 2 shows the path coefficient along with their significant levels. In our interpretation of the path coefficient, we adopted Lomax and Schumacker (2004) who posits a 3-point classification of output namely; below $0.30=$ moderate effect, 0.30 to $0.60=$ strong effect and above $0.60=$ strong effect.

Hypothesis $\mathrm{H} 1 \mathrm{a}$ and $\mathrm{H} 1 \mathrm{~b}$ proposed that research and development and new hiring will be positively related to employee engagement and social connectedness. Our path analysis confirmed a positive direct impact with the $\mathrm{H} 1 \mathrm{a}$ and $\mathrm{H} 1 \mathrm{~b}$. New hiring, therefore, demonstrates a strong, positive and significant direct effect on employee engagement (path coefficient $=0.46, \mathrm{p}<0.01)$. Thus, an increase in new hiring has a positive impact on employee engagement. Again, New hiring has a strong, positive and significant effect on social connectedness (path coefficient $=0.31, \mathrm{p}<0.01$ ). Further, H1c has a very strong, positive significant total effect on organizational innovation (path coefficient $=0.60, p<0.01$ ). Implicational, professional new hiring influences organizational innovation when mediated by social connectedness and employee engagement. Hypothesis 1a, b, and c were all supported.

$\mathrm{H} 2 \mathrm{a}$ hypothesized that research and development has a direct effect on employee engagement. The results showed $\mathrm{H} 2 \mathrm{a}$ had a strong, positive direct effect on employee engagement, (path coefficient $=0.40, \mathrm{p}<0.01)$. Again, the data was supportive of the model's predictive power. 


\section{Macrothink}

Table 3 represents the fully decomposed model deduced from Figure 3.

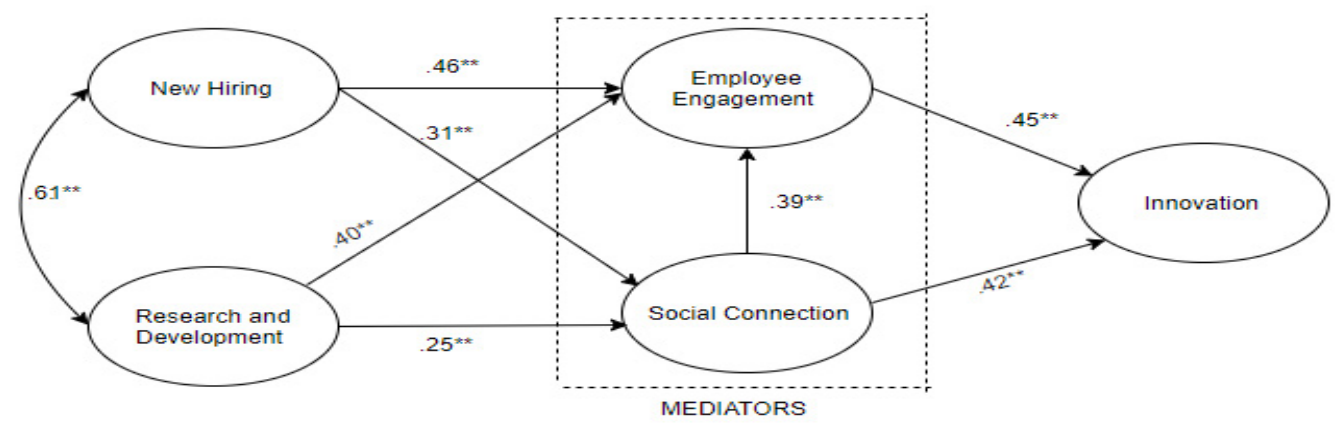

Figure 2. General Structural Model

The general model from Figure 2 shows the impact of research and development and new hiring on organizational innovation as jointly mediated by employee engagement and social connectedness.

Table 3. General Structural Model: Decomposition of total, direct and indirect effects $(\mathrm{N}=1075)$

\begin{tabular}{llllll}
\hline & Variable relations & $\begin{array}{l}\text { Direct } \\
\text { effect }\end{array}$ & Indirect effect & $\begin{array}{l}\text { Total } \\
\text { effect }\end{array}$ & $\begin{array}{l}\text { Hypothesis } \\
\text { Support }\end{array}$ \\
\hline H1a & PNH-EENG & 0.46 & - & 0.46 & Yes \\
H1b & PNH-SC & 0.31 & - & 0.31 & Yes \\
H1c & PNH-SC-EENG-INO & - & 0.60 & 0.60 & Yes \\
H2a & RD-EENG & 0.40 & - & 0.40 & Yes \\
H2b & RD-SC & 0.25 & - & 0.25 & Yes \\
H2c & RD-SC-EENG-INO & - & 0.54 & 0.54 & Yes \\
H3 & SC-EENG & 0.39 & - & 0.39 & Yes \\
H4 & SC-INO & 0.42 & - & 0.42 & Yes \\
H5 & EENG-INO & 0.45 & - & 0.45 & Yes \\
H6 & SC-EENG-INO & - & 0.84 & 0.84 & Yes
\end{tabular}

Table 3 again depicts that $\mathrm{H} 2 \mathrm{~b}$ has a moderate, direct positive effect on social connectedness, (path coefficient $=0.25, \mathrm{p}<.01$ ). The hypothesis is therefore supported. Further, hypothesis $\mathrm{H} 2 \mathrm{c}$ assumes research and development have an impact on organizational innovation through the mediating effects of social connectedness and employee engagement. $\mathrm{H} 2 \mathrm{c}$ has a strong, positive total effect on organizational innovation (path coefficient $=0.54, \mathrm{p}<.01$ ).

The hypothesis $\mathrm{H} 3$ predicted that social connectedness influences employee engagement. 


\section{Macrothink}

From the results, H3 had a strong, positive direct effect on employee engagement (path coefficient $=0.39, \mathrm{p}<.01)$. H4, on the other hand, hypothesized that social connectedness directly impacts organizational innovation. The study revealed that $\mathrm{H} 4$ had a strong positive direct effect on organizational innovation (path coefficient $=0.42, \mathrm{p}<.01$ ). Further, H5 had a strong positive direct effect on organizational innovation (path coefficient $=0.45, p<0.01$ ). Finally, H6 showed a very strong positive total effect of Social connectedness mediated by employee engagement on organizational innovation. H3, H4, H5, and H6 were all supported.

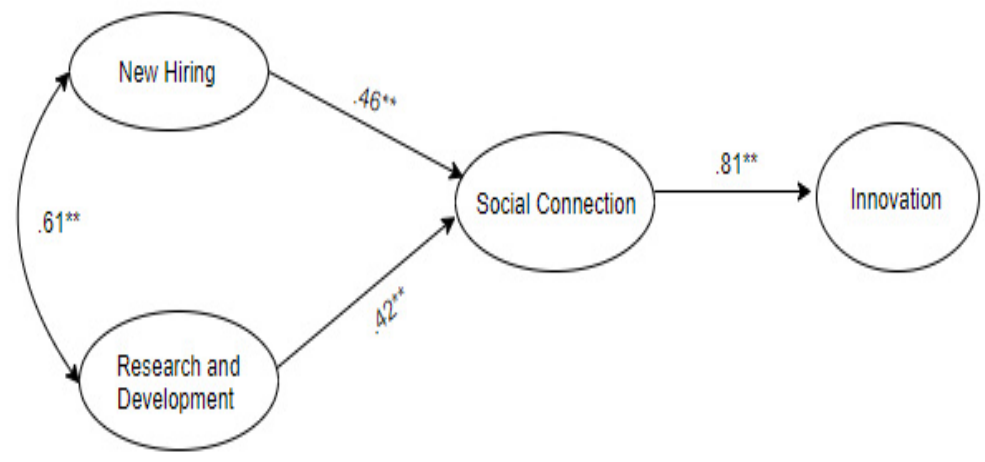

Figure 2. Submodel 1; Single Mediated effect of Social Connectedness

Figure 3 represents the impact of new hiring and research and development on organizational innovation as solely mediated by social connectedness.

To further justify the need for a joint mediated model, two sub-models were derived and tested from the general model. The sub-model 1 tested the impact of new hiring and research and development on organizational innovation in a solely mediated effect from social connectedness. The results confirmed a positive and a very strong direct and indirect effect on organizational innovation (path coefficient $=0.46,0.42, \& 82$ respectively $\mathrm{p}<0.01$ ).

Table 4. Decomposed Sub model 1

\begin{tabular}{lllll}
\hline Variable Relations & Direct effect & Indirect effect & Total effect & Hypothesis support \\
\hline PNH-SC-INO & - & 0.37 & 0.37 & Yes \\
RD-SC-INO & - & 0.34 & 0.34 & Yes
\end{tabular}

Table 4 is supportive of the hypothesis for a single mediation sub-model. However, in comparison with the jointly mediated hypothesis, where we observed a very strong positive total effect, the sub-model 1 showed a strong positive total effect. 


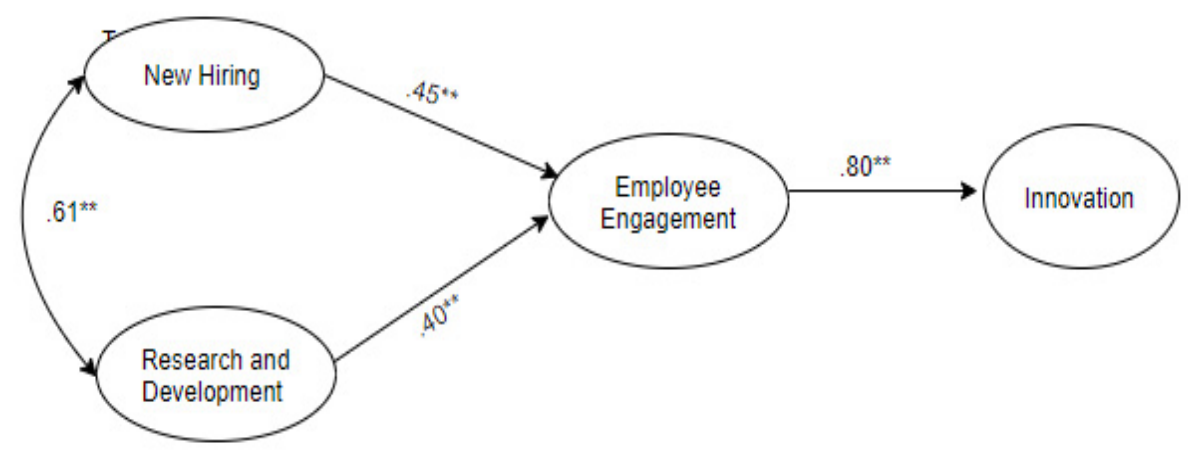

Figure 3: Figure 3: Submodel 2; Single Mediated effect of Employee engagement

Figure 4 shows the impact of new hiring and research and development on organizational innovation as solely mediated by employee engagement. The results confirmed a positive and a very strong direct and indirect effect on organizational innovation, (path coefficient $=.45$, $0.40, \& 0.80$ respectively $\mathrm{p}<0.01)$.

Table 5. Decomposed Sub model 2

\begin{tabular}{lllll}
\hline Variable Relations & Direct effect & Indirect effect & Total effect & Hypothesis support \\
\hline PNH-EENG-INO & - & 0.36 & 0.36 & Yes \\
RD-EENG-INO & - & 0.32 & 0.32 & Yes \\
\hline
\end{tabular}

Table 5 also indicated the support of the hypothesis within the single mediated sub-model. Similarly to the results in Table 4, the jointly mediated hypothesis where social connectedness and employee engagement mediate the relationship between new hiring and $R \& D$ and organizational innovation, we observed a very strong positive total effect, the sub-model 1 showed a strong positive total effect.

Observably from the General model (Figure 2) Submodel 1 (Figure 3) and sub-model 2 (figure 4) when organizations employ research and development activities and complement these activities with professional new hiring while jointly mediated by social connectedness of employees and employee engagement, a more positive impact on organizational innovation occurs as compared to the single mediation of social connectedness and employee engagement.

Further, a comparison of model fitness indices of the General model (Figure 2), sub-model 1 (Figure 3) sub-model 2 (Figure 4) was tested. The results of the comparative model fitness on the 3 models are presented in Table 6. 
Table 6. Comparative Model Fitness test

\begin{tabular}{llllllllllll}
\hline Models & NFI & TLI & CFI & \multicolumn{2}{c}{ RMSR RMSEA IFI } & RFI & GFI & AGFI PGFI PCLOSE \\
\hline Sub-model 1 & 0.908 & 0.947 & 0.931 & 0.042 & 0.040 & 0.981 & 0.941 & 0.902 & 0.876 & 0.69 & 0.899 \\
Sub-model 2 & 0.917 & 0.943 & 0.972 & 0.040 & 0.045 & 0.907 & 0.909 & 0.891 & 0.908 & 0.66 & 0.912 \\
General Model & 0.995 & 0.989 & 0.991 & 0.010 & 0.021 & 1.0 & 1.00 & 0.983 & 0.924 & 0.705 & 0.947 \\
Thresholds & $>0.09>0.09>0.09$ & $<0.05$ & $<0.05$ & $>0.09>0.09$ & $>0.09>0.09>0.50$ & $>0.09$ \\
\hline
\end{tabular}

From Table 6, the jointly mediated model outperformed the 2 sub-models in terms of their fitness. Thus, the influence of research and development and professional new hiring on organizational innovation is better enhanced by the joint mediation of social connectedness and employee engagement activities. In all fitness indexes, (NFI, TLI, DCI, RMSR, RMSEA, IFI, GFI, AGFI, and PCLOSE) the general model saw a better fitness index using the thresholds as a baseline, (Ghani et al., 2020; Roy, Modak, \& Dan, 2020).

Conclusively, the measured constructs exhibited a very strong positive relationship as proposed in our conceptual model. Our study focused on the strong mediating roles of social connectedness and employee engagement and as such did not focus on the direct effect of research and development and professional new hiring on organizational innovation.

\section{Discussion and Conclusion}

In more recent times the role of employee engagement in organizational base studies has increased. Joubert and Roodt (2019) confirmed the important role played by employee engagement in organizational performance. Further, the social connectedness of individual employees, a psychologically tested variable in acculturation studies is also gaining popularity as a major study on the acquisition and diffusion of many essential elements that aim at organizational growth (Lee et al., 2001). These two concepts in more recent times have been cited in differential studies as playing major roles in organizational interactions and innovative growth. Research and development have been a foundational explanatory variable to organizational innovation. Innovation takes place in the form of process, service or product. In addition, professional new hiring come on board in an organization with new perspective, idea, knowledge and skillset (human capital) that when cautiously integrated into existing human capital has the tendency to impact organizational innovation.

From this angle, our study aimed at exploring the dynamics and complexities of relations between the explanatory variables of organizational innovation. Through our study, a number of contributions have been made to this new dimension of organizational interactions towards innovation and sustainability.

Our study analyzed the degree to which research and development could positively impact social connectedness and employee engagement. Our results confirmed that research and development activities impact employee engagement and social connectedness. Research and development activities do not only concentrate on the product but also processes, services, organizational behavior, and the totality of measures employed by organizations to remain competitive and relevant in the market space. When General Managers and specifically 


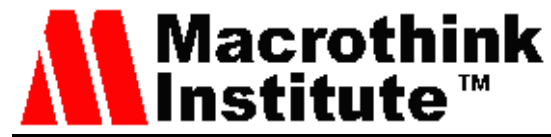

Human Resource Manager constantly invest in research and development, it will have an impact positively on social connectedness and employee engagement for organizational success.

Secondly, the role of professional new hiring integrating new ideas, perspectives, skill-sets, and knowledge has an impact on social connectedness and employee engagement. Thus, suggesting new and workable approaches experienced and practiced in their former workplace, integrating their knowledge into that of existing ones in the organization influences directly the social connectedness and employee engagement levels of the organization.

Further, our results indicate that professional new hiring and research and development activities have an indirect effect on organizational innovation through a joint mediation of social connectedness and employee engagement. Promoting and encouraging social connectivity among employees within the sector through activities that enhance cooperation and sharing of ideas, knowledge, and information, the two major sources of human capital development impact positively on organizational innovation. Further, employee engagement strategies that encompass unique opportunities for both new and old employees to share their knowledge, take on more challenging assignments, learn from others, all of which help in the reduction of rigid routines, familiarity trap and maturity trap that hinders organizational innovation (Ahuja \& Morris Lampert, 2001).

Finally, our study revealed that social connectedness is an important factor in ensuring employee engagement as it has a direct positive impact. Organizations that enhance social connectedness among their employees are more likely to promote employee engagement and subsequently innovative activities.

The study based on the findings conclude that R\&D and professional new hiring impacts on organizational innovation. The mediation of social connectedness and employee engagement respectively enhances the relationship. However, for a more efficient prediction of organizational innovation, the joint mediation of social connectedness and employee engagement is much supportive.

\section{Policy Implication}

This study supports a growing new dimension on organizational innovation determinants as well as a historic body of evidence in the same field. Organizations undertake research and development activities to remain relevant in the fast-growing competitive market space. From the findings and conclusions of the study, the following policies are recommended;

1) The driving role of research and development activities still remains a crucial factor for organizational innovation. The constant engagement in these activities and their intensity is relevant in enhancing organizational innovation for sustainability in the competitive market. However, we recommend that to further enhance the impact of research and development on organizational innovation, social connectedness and employee engagement should be encouraged as it mediates effectively in the relationship between these two key organizational variables. As suggested by Zabojnik and Bernhardt (2001), activities such as corporate tournaments, teamwork, enhance social connectedness among employees and further push higher their engagement and commitment to organizational vision. 
2) Secondly, professional new hiring in more recent times has been measured as a major source of R\&D spillover within sectors (Elisabetta, 2006). Thus, the strategic hiring of professional employees has an impact on the innovation of the organization. However, it lies in the key role of the human resource manager to do a better job analysis to enjoy an optimum benefit from the new employees as not all new employees are equipped with adequate levels of human capital to influence organizational innovation (Noe, Hollenbeck, Gerhart, \& Wright, 2015). We, therefore, recommend when necessary 'poaching' of professionals who fits perfectly in the job analysis conducted by human resource management. Further, to enhance the impact of professional new hiring on organizational innovation, we again recommend policy driven social connectedness and employee engagement activities at the organizational level to fully benefit from the relation.

\section{Acknowledgment}

This work was supported by the National Science Foundation of China under Grant number 71371087.

\section{References}

Ahmad, A., Kura, K. M., Bibi, P., Khalid, N., \& Jaaffar, A. R. (2019). Effect of Compensation, Training, and Development and Manager Support on Employee Commitment: The moderating effect of Co-worker Support. 2019, 10(2), 17. https://doi.org/10.23925/2179-3565. 2019v10i2p39-55

Ahuja, G., \& Morris Lampert, C. (2001). Entrepreneurship in the large corporation: A longitudinal study of how established firms create breakthrough inventions. Strategic Management Journal, 22(6-7), 521-543. https://doi.org/10.1002/smj.176

Awaworyi Churchill, S., Ugur, M., \& Luong, H. (2020). What do we know about R\&D spillovers and productivity? Meta-analysis evidence on heterogeneity and statistical power. Research Policy, 49(1), 1-16. https://doi.org/10.1016/j.respol.2019.103866

Bagozzi, R. P. (1982). Theoretical Concepts, Measurement, and Meaning, in, vol. 2 C. Fornell (Ed.) A Second Generation of Multivariate Analysis: Praeger.

Bamberger, P. A., Biron, M., \& Meshoulam, I. (2014). Human resource strategy: Formulation, implementation, and impact: Routledge. https://doi.org/10.4324/97802030 75838

Bantel, K. A., \& Jackson, S. E. (1989). Top management and innovations in banking: Does the composition of the top team make a difference? Strategic Management Journal, 10(S1), 107-124. https://doi.org/10.1002/smj.4250100709

Battistelli, A., Odoardi, C., Vandenberghe, C., Di Napoli, G., \& Piccione, L. (2019). Information sharing and innovative work behavior: The role of work-based learning, challenging tasks, and organizational commitment. Human Resource Development Quarterly. https://doi.org/10.1002/hrdq.21344

Bedford, D. S., Bisbe, J., \& Sweeney, B. (2019). Performance measurement systems as generators of cognitive conflict in ambidextrous firms. Accounting, Organizations and Society, 72, 21-37. https://doi.org/10.1016/j.aos.2018.05.010 


\section{Macrothink}

Bernal, P., Maicas, J. P., \& Vargas, P. (2019). Exploration, exploitation and innovation performance: disentangling the evolution of the industry. Industry and Innovation, 26(3), 295-320. https://doi.org/10.1080/13662716.2018.1465813

Birasnav, M., Chaudhary, R., \& Scillitoe, J. (2019). Integration of Social Capital and Organizational Learning Theories to Improve Operational Performance. Global Journal of Flexible Systems Management, 1-15. https://doi.org/10.1007/s40171-019-00206-9

Call, M. L., Nyberg, A. J., Ployhart, R. E., \& Weekley, J. (2015). The dynamic nature of collective turnover and unit performance: the impact of time, quality, and replacements. Academy of Management Journal, 58(4), 1208-1232. https://doi.org/10.5465/amj.2013.0669

Camarinha-Matos, L. M., Afsarmanesh, H., Galeano, N., \& Molina, A. (2009). Collaborative networked organizations-Concepts and practices in manufacturing enterprises. Computers \& Industrial Engineering, 57(1), 46-60. https://doi.org/10.1016/j.cie.2008.11.024

Chen, Z., Liu, Z., Suárez Serrato, J. C., \& Xu, D. Y. (2018). Notching R\&D investment with corporate income tax cuts in China (0898-2937). https://doi.org/10.3386/w24749

Choi, C., \& Yi, M. H. (2018). The Internet, R\&D expenditure and economic growth. Applied Economics Letters, 25(4), 264-267. https://doi.org/10.1080/13504851.2017.1316819

Collins, J. C. (2001). Good to Great: Why Some Companies Make Leap... and Others Don't: Son's Books.

Creelman, D. (2019). Hiring stars can hurt your company's performance. HR Future, 2019(May 2019), 12-13.

Dhaoui, A., \& Jouini, F. (2019). R\&D Investment, Governance and Management Entrenchment. International Journal of Financial Economics and Econometrics, 6(2), 69-90.

Dinçer, H., Yüksel, S., Adalı, Z., \& Aydın, R. (2019). Evaluating the Role of Research and Development and Technology Investments on Economic Development of E7 Countries Organizational Transformation and Managing Innovation in the Fourth Industrial Revolution (pp. 245-263): IGI Global. https://doi.org/10.4018/978-1-5225-7074-5.ch013

Effendi, M., \& Matore, E. (2019). Structural Equation Model (SEM) in Assimilating EQ, SQ, and AQ for Mechanical Students Context. Proceedings of Mechanical Engineering Research Day, 230-231.

Elisabetta, M. (2006). Is workers' mobility a source of R\&D spillovers?: Evidence of the effects of innovative activities on wages. International Journal of Manpower, 27(2), 169-188. https://doi.org/10.1108/01437720610666191

Ferris, S. P., Javakhadze, D., \& Rajkovic, T. (2017). CEO social capital, risk-taking, and corporate policies. Journal of Corporate Finance, 47, 46-71. https://doi.org/10.1016/ j.jcorpfin.2017.09.003

Fornell, C., \& Larcker, D. F. (1981). Structural equation models with unobservable variables and measurement error: Algebra and statistics: SAGE Publications Sage CA: Los Angeles, CA. https://doi.org/10.2307/3150980

Foskett, R. (2005). A collaborative partnership between HE and employers: a study of workforce development. Journal of Further and Higher Education, 29(3), 251-264. https://doi.org/10.1080/03098770500166868 


\section{MInstitute Macrothink $_{\text {Int }}$}

Gallivan, M. J. (2001). Organizational adoption and assimilation of complex technological innovations: development and application of a new framework. ACM SIGMIS Database: the DATABASE for Advances in Information Systems, 32(3), 51-85. https://doi.org/10.1145/ 506724.506729

Ghani, U., Zhai, X., Spector, J. M., Chen, N.-S., Lin, L., Ding, D., \& Usman, M. (2020). Knowledge hiding in higher education: the role of interactional justice and professional commitment. Higher Education, 79(2), 325-344. https://doi.org/10.1007/s10734-019-00412-5

Herstad, S. J., Sandven, T., \& Ebersberger, B. (2015). Recruitment, knowledge integration and modes of innovation. Research Policy, 44(1), 138-153. https://doi.org/10.1016/j.respol. 2014.06.007

Holmquist, M., \& Johansson, A. (2019). Employee-Driven Innovation: An Intervention Using Action Research. Technology Innovation Management Review, 9(5). https://doi.org/10.22215/ timreview/1240

Huxham, C., \& Vangen, S. (2013). Managing to collaborate: The theory and practice of collaborative advantage: Routledge.

Jeong, I., \& Shin, S. J. (2019). High-performance work practices and organizational creativity during organizational change: a collective learning perspective. Journal of Management, 45(3), 909-925. https://doi.org/10.1177/0149206316685156

Joubert, M., \& Roodt, G. (2019). Conceptualizing and measuring employee engagement as a role-related, multi-level construct. Acta Commercii, 19(1), 1-17. https://doi.org/10.4102/ ac.v19i1.605

Kawajiri, K., Goto, T., Sakurai, S., Hata, K., \& Tahara, K. (2020). Development of life cycle assessment of emerging technology at the research and development stage: A case study on single-wall carbon nanotube produced by the super-growth method. Journal of Cleaner Production, 120015. https://doi.org/10.1016/j.jclepro.2020.120015

Knoke, D., \& Kalleberg, A. L. (1994). Job training in US organizations. American sociological review, 59(4), 537. https://doi.org/10.2307/2095930

Kogut, B., \& Zander, U. (1992). Knowledge of the Firm, Combinative Capabilities, and the Replication of Technology. Organization Science, 3(3), 383-397. https://doi.org/10.1287/ orsc.3.3.383

Landherr, A., Friedl, B., \& Heidemann, J. (2010). A Critical Review of Centrality Measures in Social Networks. Business \& Information Systems Engineering, 2(6), 371-385. https://doi.org/10.1007/s12599-010-0127-3

Lee, R. M., Draper, M., \& Lee, S. (2001). Social connectedness, dysfunctional interpersonal behaviors, and psychological distress: Testing a mediator model. Journal of counseling psychology, 48(3), 310. https://doi.org/10.1037/0022-0167.48.3.310

Li, W. C., \& Hall, B. H. (2018). Depreciation of business R\&D capital. Review of Income and Wealth. https://doi.org/10.1111/roiw.12380

Liedtka, J. M. (1996). Collaborating across lines of business for competitive advantage. Academy of management perspectives, 10(2), 20-34. https://doi.org/10.5465/ame.1996.96061 61550 


\section{MInstitute ${ }_{\text {Mnk }}^{\text {Macrothin }}$}

Human Resource Research

ISSN 1948-5441

2020, Vol. 4, No. 1

Liu, C., \& Xia, G. (2018). Research on the dynamic interrelationship among R\&D investment, technological innovation, and economic growth in China. Sustainability, 10(11), 4260. https://doi.org/10.3390/su10114260

Liu, N., \& Fan, F. (2020). Threshold effect of international technology spillovers on China's regional economic growth. Technology Analysis \& Strategic Management, 1-13. https://doi.org/10.1080/09537325.2020.1729977

Lomax, R. G., \& Schumacker, R. E. (2004). A beginner's guide to structural equation modeling: psychology press. https://doi.org/10.4324/9781410610904

Marchington, M. (2015). Human resource management (HRM): Too busy looking up to see where it is going long term? Human Resource Management Review, 25(2), 176-187. https://doi.org/10.1016/j.hrmr.2015.01.007

Noe, R. A., Hollenbeck, J. R., Gerhart, B., \& Wright, P. M. (2015). Human resource management. Gaining a Competitive.

Nyberg, A. J., Moliterno, T. P., Hale Jr, D., \& Lepak, D. P. (2014). Resource-based perspectives on unit-level human capital: A review and integration. Journal of Management, 40(1), 316-346. https://doi.org/10.1177/0149206312458703

O'Leary-Kelly, S. W., \& J. Vokurka, R. (1998). The empirical assessment of construct validity. Journal of operations management, 16(4), 387-405. https://doi.org/10.1016/S0272-6963(98) 00020-5

Ogunmokun, O. A., Eluwole, K. K., Avci, T., Lasisi, T. T., \& Ikhide, J. E. (2020). The propensity to trust and knowledge sharing behavior: An evaluation of importance-performance analysis among Nigerian restaurant employees. Tourism Management Perspectives, 33, 100590. https://doi.org/10.1016/j.tmp.2019.100590

Romer, P. M. (1989). Human Capital And Growth: Theory and Evidence. The National Bureau of Economic Research. https://doi.org/10.3386/w3173

Rousseau, D. M. (1997). Organizational behavior in the new organizational era. Annual review of psychology, 48(1), 515-546. https://doi.org/10.1146/annurev.psych.48.1.515

Roy, S., Modak, N., \& Dan, P. (2020). A Framework of Strategic Role for Developing Sustainable Products: Structural Equation Modeling Approach Sustainable Waste Management: Policies and Case Studies (pp. 647-656). Springer. https://doi.org/10.1007/ 978-981-13-7071-7_58

Saidi, K., \& Mongi, C. (2018). The Effect of Education, R\&D, and ICT on Economic Growth in High-Income Countries. Economics Bulletin, 38(2), 810-825.

Schumpeter, J. (1934). The theory of economic development (R. Opie (trans.) from the 2nd German edition [1926]): Cambridge, MA: Harvard University Press.

Shujahat, M., Sousa, M. J., Hussain, S., Nawaz, F., Wang, M., \& Umer, M. (2019). Translating the impact of knowledge management processes into knowledge-based innovation: The neglected and mediating role of knowledge-worker productivity. Journal of Business Research, 94, 442-450. https://doi.org/10.1016/j.jbusres.2017.11.001

STANLEY, S., \& FREDERICK, D. H. (2020). Environmental Concern among the Youth towards Sustainable Green Lifestyle. Our Heritage, 68(30), 524-531. 


\section{Macrothink}

Strandholm, J. C., Espinola-Arredondo, A., \& Munoz-Garcia, F. (2018). Regulation, free-riding incentives, and investment in $\mathrm{R} \& \mathrm{D}$ with spillovers. Resource and Energy Economics, 53, 133-146. https://doi.org/10.1016/j.reseneeco.2018.04.002

Tomar, J. S. (2020). Employee Engagement in India: Organizational Effectiveness, People, and Performance in IT Companies Handbook of Research on the Role of Human Factors in IT Project Management (pp. 420-451): IGI Global. https://doi.org/10.4018/978-1-7998-1279 $-1 . \operatorname{ch} 023$

Tomar, J. S., Khandelwal, R., \& Jain, R. (2020). Role of Employee Engagement in Reducing Workplace Deviance Analyzing Workplace Deviance in Modern Organizations (pp. 229-269): IGI Global. https://doi.org/10.4018/978-1-5225-9996-8.ch012

Turner, P. (2020). A Model for Employee Engagement Employee Engagement in Contemporary Organizations (pp. 85-111): Springer. https://doi.org/10.1007/978-3-03036387-1

Ulrich, D., \& Dulebohn, J. H. (2015). Are we there yet? What's next for HR? Human Resource Management Review, 25(2), 188-204. https://doi.org/10.1016/j.hrmr.2015.01.004

Varga, A., Sebestyén, T., Szabó, N., \& Szerb, L. (2020). Estimating the economic impacts of a knowledge network and entrepreneurship development in the smart specialization policy. Regional Studies, 54(1), 48-59. https://doi.org/10.1080/00343404.2018.1527026

Wang, T., \& Zatzick, C. D. (2019). Human Capital Acquisition and Organizational Innovation: A Temporal Perspective. Academy of Management Journal, 62(1), 99-116. https://doi.org/ 10.5465/amj.2017.0114

Xia, L., \& Yang, Z. (2019). Research on Factors Influencing Core Competitiveness of Internet Enterprises Based on AMOS Model. Paper presented at The 4th International Conference on Economy, Judicature, Administration and Humanitarian Projects (JAHP 2019). https://doi.org/10.2991/jahp-19.2019.105

Yukiko, M. (2016). Linking Knowledge Absorption and Transmission Toward Innovation in R\&D Organizations. Proceedings of the European Conference on Knowledge Management, 667-675.

Zabojnik, J., \& Bernhardt, D. (2001). Corporate tournaments, human capital acquisition, and the firm Size-Wage relation. The Review of Economic Studies, 68(3), 693-716. https://doi.org/10.1111/1467-937X.00186

\section{Copyright Disclaimer}

Copyright for this article is retained by the author(s), with first publication rights granted to the journal.

This is an open-access article distributed under the terms and conditions of the Creative Commons Attribution license (http://creativecommons.org/licenses/by/3.0/). 